\title{
EFFECTS OF GARLIC CLOVE, NEEM AND EUCALYPTUS LEAF EXTRACT ON MATING BEHAVIOUR, OVIPOSITION AND ADULT EMERGENCE OF PULSE BEETLE, Callosobruchus maculatus
}

\author{
S. Akter, N. Nahar and M. Rahman \\ Department of Entomology, Bangladesh Agricultural University \\ Mymensingh-2202, Bangladesh
}

\begin{abstract}
Experiments were conducted in the laboratory to study the effects of garlic clove, neem and eucalyptus leaf extracts on mating behaviour, oviposition and adult emergence of pulse beetle, Callosobruchus maculatus. Intensity of seed damage and weight loss of gram seeds were also recorded. The results showed that the mating frequency, mating duration, oviposition, adult emergence of pulse beetle and weight loss of gram seeds were reduced significantly after application of the extracts. Among the extracts, neem leaf extracts showed lowest mating frequency (1), mating duration (3.66 minutes), lowest number of laid eggs (27.33), adult emergence (11.67), seed damage $(6.89 \%)$ and weight loss $(2.53 \%)$. On the other hand, garlic clove extract showed highest mating frequency (1.67), mating duration (4.67 minutes), highest number of laid eggs (40.33), adult emergence (18.66), seed damage $(9.63 \%)$ and weight loss $(3.73 \%)$. In the same way eucalyptus leaf extract showed $2^{\text {nd }}$ highest mating frequency (1.5), mating duration (4.5 minutes), eggs laid (38.67), adult emergence (15.67), seed damage (9.25) and seed weight loss $(3.33 \%)$. Considering efficacy of all extracts, it was found that the order of toxicity was neem leaf extract>eucalyptus leaf extract> garlic clove extract.
\end{abstract}

Key Words : Callosubruchus maculatus, Eucalyptus, Garlic, Mating behaviour, Neem, Oviposition and adult emergence

\section{INTRODUCTION}

Pulses are the main source of plant protein of the developing countries. It plays a vital role in the nutrition of the people of Bangladesh. Pulse production is gradually decreasing day by day due to attack of several pests in the field and storage. Among the pests, pulse beetle, Callosobruchus maculatus causes great damage to pulses and is widespread throughout the tropical and sub-tropical regions (Menash, 1986). This species is so severe that they may cause total damage to the stored pulses. The adult pulse beetle mate and oviposit on pulse seeds. After hatching, the larva bores into the seeds and starts feeding inside partially or completely in the stored condition resulting the damage of whole seeds which later become unfit for human consumption and sowing in field. The reports of such losses from different parts of the world vary from 10-95 percent under normal godown as well as field condition and the percentage of damage increase with the duration of storage under normal condition (Gujar and Yadav, 1978). They reported 
$55-60 \%$ loss in seed weight and $45.5-66.3 \%$ loss in protein content due to infestation of pulse beetle.

In storage, pulse beetle is chiefly controlled by synthetic insecticides which give rise to many undesirable problems such as resistant pest population, pest resurgence, toxic residues, environmental pollution and health hazards. It is now urgently needed to use safe but effective biodegradable pesticide with less toxic effect. The biologically active natural plant products may play a significant role in this regard. The present study therefore undertaken to find out the effectiveness of garlic clove, neem and eucalyptus leaf extract on the mating behaviour, oviposition and adult emergence of pulse beetle.

\section{MATERIALS AND METHODS}

The studies were made using gram seeds in the laboratory of the Department of Entomology, Bangladesh Agricultural University, Mymensingh during May to September 2006.

The test insects were collected from the laboratory of the Department of Entomology, Bangladesh Agricultural University. The collected adult beetles were separated from the infested seeds and transferred to fresh seeds of gram for continuous growing in a plastic container. The beetles were allowed for free mating and oviposition for a period of seven days. The gram seeds containing egg were kept for emergence of next generation beetles.

One hundred gram cloves of garlic were taken into an electronic blender with $100 \mathrm{ml}$ of water. For obtaining fine extract, the blended mixture was filtered with fine cloth and the extract was considered as 50\% concentration. Then $10 \mathrm{ml}$ of the extract was added to 90 $\mathrm{ml}$ distilled water to get $5 \%$ concentration of garlic clove. Similarly neem and eucalyptus leaf extracts were made from fresh leaves.

Male and female adult beetles were treated separately with 5\% neem leaf extract with the help of a dropper. After 5 minutes, one treated male and female beetles were released into a petridish containing $10 \mathrm{~g}$ of fresh gram seeds and observed for three hours. The same process was followed for garlic clove and eucalyptus leaf extract. Three replications were used for each treatment with a control. Then the mating frequency and mating duration were recorded.

One pair of newly emerged treated beetles was released in a petridish containing $50 \mathrm{~g}$ of fresh and insect free seeds. Three replications were maintained for each treatment with a control. Then the petridishes were kept in a large metal cage. The oviposition was recorded after 7 days of the release of the beetle. The laid eggs were counted by hand lens. The pulse beetles started emerging after 26 days of egg laying. The emerged beetles were counted and removed every day from the petridish. Seeds with hole(s) were considered as damaged seeds. Total number of seeds and number of damaged seeds of each petridish of each replication were counted. 
After hatching the larvae entered into the seeds and fed on the cotyledons. The gram seeds were separated from dust particle and dead bodies of pulse beetle by sieving and winnowing. The cleaned infested seeds were weighed separately and the percentage of seed weight losses was calculated.

The data were statistically analyzed in accordance with three factors Completely Randomized Design (CRD) and treatment mean values were compared by Duncan's Multiple Range Test (DMRT).

\section{RESULTS AND DISCUSSION}

Mating of pulse beetle, C. maculatus occurred immediately after the emergence of adult. Females usually controls mating chemically by the secretion of sex pheromone (Tanaka et al., 1981). The mating success of an unmated pair depends on the chemical activity (production of sex pheromone) of the female and the physical behavioral activity (response to sex pheromone) of the male.

The data on mating frequency and mating duration are presented in Table 1 . In all the three replications the couples were mated. The highest mating frequency (2) was found in control whereas the lowest mating frequency (1) was found in neem leaf extract treated beetles. The second highest mating frequency (1.67) was found in garlic clove extract treated beetles. The highest mating duration ( 5 minutes) was found in control which was significantly different from other treatments. The higher mating duration (4.5 minutes) and (4.67 minutes) were found in eucalyptus leaf extract and garlic clove extract treated beetles, respectively. The lowest mating duration (3.66 minutes) was found in neem leaf extract treated beetles.

Table 1. Effect of different extracts on mating frequency and mating duration of pulse beetle, Callosobruchus maculatus

\begin{tabular}{c|c|c}
\hline Name of extracts & Mating frequency & Mating duration (minutes) \\
\hline Neem leaf & $1.00 \mathrm{~d}$ & $3.66 \mathrm{~d}$ \\
Eucalyptus leaf & $1.50 \mathrm{c}$ & $4.50 \mathrm{c}$ \\
Garlic clove & $1.67 \mathrm{~b}$ & $4.67 \mathrm{~b}$ \\
Control & $2.00 \mathrm{a}$ & $5.00 \mathrm{a}$ \\
\hline
\end{tabular}

Within column values having same letter(s) don't differ significantly at $5 \%$ level of probability by DMRT

Lowest mating rate and duration of neem leaf extract treated beetle may be due to the reduction of behavioral activities of males by the toxicity of the neem leaf extract and/ or its pungent odour. The treated beetles can't perform normal mating behavior because the leaf extracts may chemically hamper the pheromone production by females and the males may fail to recognize the pheromone in the presence of the extract. The results of this study supported the findings of Ahmed et al. (2001) who stated that neem oil 
treatment had significant effect on mating frequency and duration of azuki bean weevil, C. chinensis.

The data on number of eggs laid and adult emergence are presented in Table 2. The number of eggs laid by different extracts treated beetles were significantly different. The lowest number of eggs (27.33) laid by neem leaf extract treated adult females and comparatively higher eggs (38.67) were recorded in eucalyptus leaf extract and garlic clove extract (40.33) treated beetles. The highest number of eggs were found in control (63.67). The present results on the rate of oviposition was in agreement with the results reported by Rajesus et al. (1989); Prakash and Rao (1990). They reported that the prevention of oviposition might be due to the chemical properties of the tested materials.

Table 2. Effect of different extracts on oviposition and adult emergence of pulse beetle, Callosobruchus maculates

\begin{tabular}{lcc}
\hline \multicolumn{1}{c|}{ Name of extracts } & Mean number of eggs & Mean number of emerged beetles \\
\hline Neem leaf & $27.33 \mathrm{~d}$ & $11.67 \mathrm{~d}$ \\
Eucalyptus leaf & $38.67 \mathrm{c}$ & $15.67 \mathrm{c}$ \\
Garlic clove & $40.33 \mathrm{~b}$ & $18.66 \mathrm{~b}$ \\
Control & $63.67 \mathrm{a}$ & $21.67 \mathrm{a}$ \\
\hline
\end{tabular}

Within column values having same letter(s) don't differ significantly at $5 \%$ level of probability by DMRT

The mean number of adult emergence was found higher in control (21.67), in contrast with other treatments. The lowest number of adult emergence was found in neem leaf extract treated beetles (11.67). Incase of garlic clove and eucalyptus leaf extract treated beetle the number of emerged adult beetles was 18.66 and 15.67, respectively. This result supported the findings of Tebkew and Mekasha (2002) who stated that leaf extract decrease adult emergence of pulse beetle.

Table 3. Effect of different extracts on damage and weight loss of gram seed

\begin{tabular}{l|c|c}
\hline \multicolumn{1}{c|}{ Name of extracts } & Damaged seed $(\%)$ & Weight loss $(\%)$ \\
\hline Neem leaf & $6.89 \mathrm{c}$ & $2.53 \mathrm{~d}$ \\
Eucalyptus leaf & $9.25 \mathrm{~b}$ & $3.33 \mathrm{c}$ \\
Garlic clove & $9.63 \mathrm{~b}$ & $3.73 \mathrm{~b}$ \\
Control & $11.89 \mathrm{a}$ & $4.53 \mathrm{a}$ \\
\hline
\end{tabular}

Within column values having same letter(s) don't differ significantly at $5 \%$ level of probability by DMRT

The percentage of seed damage were ranged from 6.89 to $11.89 \%$. The lowest percentage of damaged seeds was found in neem leaf extract $(6.89 \%)$ which was significantly different from others. The highest percentage of damage seeds was found in control $(11.89 \%)$ and higher in eucalyptus leaf extract $(9.25 \%)$ and garlic clove extract $(9.63 \%)$. 
Umrao and verma (2002) reported that the various plant products reduced amount of seed damage caused by C. chinensis.

The seed weight losses caused by the beetle were found significantly different in different treatments. The highest loss was observed in control $(4.53 \%)$ and higher in eucalyptus leaf extract $(3.33 \%)$ and garlic clove extract $(3.73 \%)$ treated beetles. The lowest seed weight loss $(2.53 \%)$ was found in neem leaf extract $(6.89 \%)$ treated beetles. The active chemical azadirachtin of the neem products might be responsible for lower damage of the seeds. Similar results were also found by Misra (2000); Pandey and Singh (1997).

Considering efficacy of all treatments, it was found that the order of toxicity was neem leaf extract>Eucalyptus leaf extract $>$ Garlic clove extract. The biological activity of plant extracts is due to the various compounds present in the extracts. Further investigation is needed to identify the active compounds of the extracts responsible for its activity and to examine the effect of those extracts against a wider insecticidal activity.

\section{REFERENCES}

Ahmed, K. S., Yasui, Y. and Ichikawa, T. 2001. Effects of neem oil on mating and oviposition behavior of adzuki bean weevil, Callosobruchus chinensis L. (Coleoptera : Bruchidae). Pakistan J. Biol. Sci., 4 : 1371-1373.

Gujar, G. T. and Yadav, T. D. 1978. Feeding Callosobruchus maculatus (Fab.) and Callosobruchus chinensis (Linn.) in green gram. Indian J. Entomol., 40(2) : 108-112.

Menash, G. W. K. 1986. Infestation potential of Bruchid on cowpea cultivars stored under subtropical conditions. J. Fac. Agric. Univ. Switzerland., 7(6) : 781-784.

Misra, H. P. 2000. Effectiveness of indigenous plant products against the pulse beetle, Callosobruchus chinensis on stored black gram. Indian J. Entomol., 62(2) : 218-220.

Pandey, N. K. and Singh, S. C. 1997. Effect of neem bark powder on infestation of pulse beetle, Callosobruchus chinensis in stored chickpea. Indian J. Entomol., 59(2) : 161-163.

Prakash, A. and Rao, J. 1990. Leaves of begonia as a pulse grain protectant. Indian J. Entomol., 51(2) : 192-195.

Rajesus, M. B., Mainin, H. A., Ohsawa, K. and Yamamoto, I. 1989. Insecticidal action of several plants to Calloosobruchus chinensis L. In: Proc. 2nd Int. Symp. On bruchids and legumes held at Okayama, Japan, September 6-9. pp. 91-100.

Tanaka, K., Ohsawa, K., Honda, H and Yamamoto, I. 1981. Copulation release pheromone, erectin, from the azuki bean weevil (Calloosobruchus chinensis L.) . J. Pestic. Sci., 6 : 75-82.

Tebkew, D. and Mekasha, C. 2002. The efficacy of some botanicals in controlling azuki bean beetle, Callosobruchus chinensis in stored chick pea. Trop. Sci.., 42(4) : 192-195.

Umrao, R. S. and verma, R. A. 2002. Effectiveness of some plant products against pulse beetle on pea. Indian J. Entomol., 64(4) : 451-453. 